\title{
Drought Occurrence in Central European Mountainous Region (Tatra National Park, Slovakia) within the Period 1961-2010
}

\author{
Jaroslav Vido, ${ }^{1}$ Tsegaye Tadesse, ${ }^{2}$ Zbyšek Šustek, ${ }^{3}$ Radoslav Kandrík, ${ }^{1}$ Miriam Hanzelová, ${ }^{1}$ \\ Jaroslav Škvarenina, ${ }^{1}$ Jana Škvareninová, ${ }^{4}$ and Michael Hayes ${ }^{2}$ \\ ${ }^{1}$ Department of Natural Environment, Faculty of Forestry, Technical University in Zvolen, T.G. Masaryka 24, 96053 Zvolen, Slovakia \\ ${ }^{2}$ The National Drought Mitigation Centre, University of Lincoln, 816 Hardin Hall, 3310 Holdrege Street, Lincoln, NE 68583-0988, USA \\ ${ }^{3}$ Institute of Zoology, Slovak Academy of Sciences, Dúbravská cesta 9, 84506 Bratislava, Slovakia \\ ${ }^{4}$ Department of Applied Ecology, Faculty of Environmental Sciences, Technical University in Zvolen, T. G. Masaryka 24, \\ 96053 Zvolen, Slovakia
}

Correspondence should be addressed to Jaroslav Vido; vido@tuzvo.sk

Received 29 May 2015; Revised 7 October 2015; Accepted 18 October 2015

Academic Editor: Mohsin Hafeez

Copyright (C) 2015 Jaroslav Vido et al. This is an open access article distributed under the Creative Commons Attribution License, which permits unrestricted use, distribution, and reproduction in any medium, provided the original work is properly cited.

Drought has recently become a significant topic in the Central European region. It has been observed that the drought phenomenon has severe impacts on the agriculture, hydrology, social, and economic sectors of lowland areas. This study focuses on how drought, defined as a precipitation shortage, occurs in higher altitudes of the Tatra National Park (Tatra Mts., Slovakia), which is a significant biological reserve of the Central European fauna and flora. The main goals of this research include identifying drought variability and its characteristics over the Tatra National Park in the West Carpathians (Slovakia), especially to characterizing drought variability and its spatial pattern across the Tatra National Park from 1961 to 2010 using the Standardized Precipitation Index (SPI) and standard Geographic Information System (GIS) methods. The results showed that frequency of drought occurrence has cyclic pattern with approximately 30 -year period. The spatial analyses showed that precipitation shadow of the mountains influences the risk of drought occurrence. The drought-prone areas over the mountains are also identified.

\section{Introduction}

Drought, as a natural hazard resulting from precipitation deficits, causes various impacts in almost all types of ecosystem around the globe $[1,2]$. The Central European region is no exception [3-5]. Crop yield failure in agricultural production $[3,6]$, hydrological droughts $[7,8]$, wildfires $[9,10]$, and bark beetle outbreaks [11, 12] are only few examples of drought-related impacts in Central European ecosystems. These impacts were observed during severe drought episodes that were previously relatively infrequent in the Central European region [13, 14]. However observed changes in precipitation patterns in the last few decades, as well as projected changes in future, imply an increase in number of drought episodes in the area $[15,16]$. Despite this observed fact, there are local variabilities in the precipitation patterns and its severity. For example Škvarenina et al. [17] and Faško et al. [18] have found that an increase in drought frequency applies more across southern Slovakia as compared to the northern Slovakia (includes the Tatra National Park, a mountainous area), where significantly increasing trends of precipitation amounts were observed over the past 20 years.

However Niedźwiedź et al. [19] argued that this trend has a cyclic character with a period of about 30 years. In addition the author indicated that this wet climate feature has already begun to subside. The argument of the precipitation cyclic pattern has also been confirmed by Pekárová et al. [20] based on the long-term observations of water levels on the Central European rivers. Thus, this potentially anticipated change in precipitation patterns toward drier conditions in synergy with increasing temperature in the lower and middle altitudes over the Tatra National Park [21] could consequently exacerbate drought severity and its impacts.

Because of the controversial facts presented in the literature dealing with precipitation patterns in the area of northern Slovakia, where the Tatra National Park is located, 
there is a more urgent need in understanding drought as a potential natural hazard and its spatial distribution features. This is very important because the Tatra National Park is unique by its high species diversity, high number of endemic animals (alpine marmot [Marmota marmota latirostris], Tatra chamois [Rupicapra rupicapra tatrica], Carabids [Deltomerus tatricus, Nebria tatrica]) and plants (Cerinthe glabra subsp. tatrica, Primula halleri subsp. platyphylla) [22-24] and specific cultural landscape structures. That is acknowledged by the membership of this park in the UNESCO world network of biosphere reserves since 1993.

However, in assessing the drought across the Tatra National Park, better understanding and consideration of the topographic impact on precipitation are needed including the strong effect created over the lee ward side of the Tatra mountain ridge, ridges of surrounding mountains, and local precipitation shadows in particular mountain valleys. These orographic features significantly influence spatial precipitation distribution that may exacerbate the drought impacts in the area [25]. In addition, it is necessary to consider the relatively higher precipitation amount compared to potential evapotranspiration in the mountain areas of the National Park [17]. For example, edificator tree species in the forest ecosystem such as spruce have normally more water (enough soil moisture) during the growing period, as characterized by the water balance method (i.e., precipitation minus evapotranspiration) calculated by Škvarenina et al. [17]. Therefore, a certain resistance level of ecosystems at higher altitudes due to short-lasting precipitation fluctuations is expected [26]. However, long-lasting subnormal precipitation periods have significant impacts on ecosystems in the Tatra National Park such as weakening of tree condition [12], increase of wild fire risk [27], changes in population dynamics of climate sensitive pests [28], and depletion of groundwater in the creeks watersheds [29] that causes significant impacts on qualitative and quantitative composition of benthic macrofauna [30]. Thus, better understanding of drought characteristics over the mountainous region is helpful for managing the Tatra National Park and preservation of its biodiversity. For instance, spatial information of drought prone areas could be used for improvement of the fire prevention plan. Other examples of usage are detection of biotopes with lower ecological stability under drought influence, because such localities could be source for future outbreaks of biotic pests [11].

The main goal of this study is to characterize drought variability and its characteristics across the Tatra National Park as an integral part of Tatra Mts. (Slovakia) in the period 1961-2010.

In this study the time series trend analysis of The Standardized Precipitation Index (SPI) [31] for 12 months at the stations in the area of the Tatra Mts. and the spatial patterns of drought episode occurrences across the Tatra National Park have been investigated. SPI has been used because of several advantages compared to other drought indices, for example, the requirement of fewer input variables, simplicity of calculation, and comparability of droughts considering the time and place (because the SPI is a dimensionless index) [32, 33]. The reason to use 12-month SPI for long-term drought

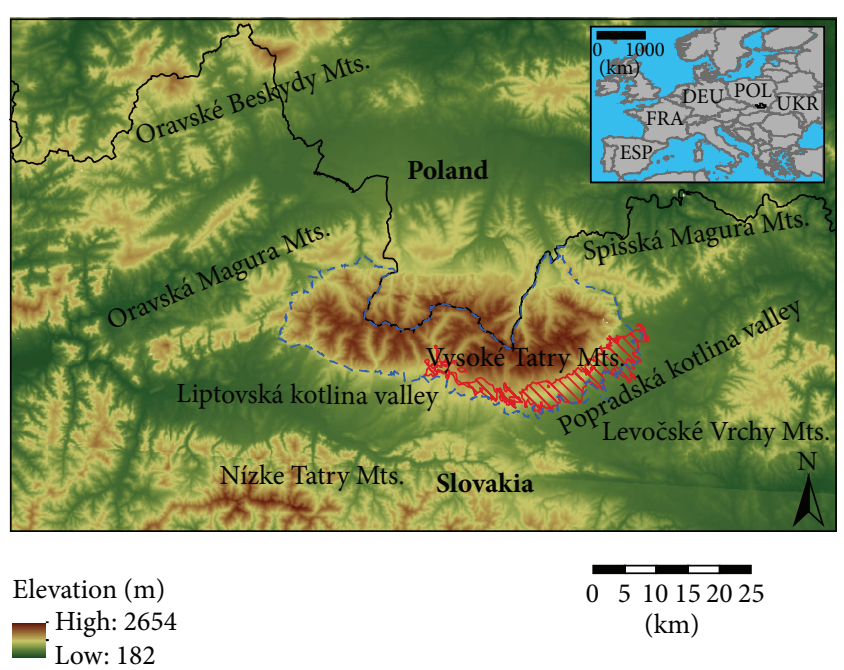

FIGURE 1: Geographical and geomorphological situation around the Tatra Mts. and Tatra National Park. Solid line represents state boundary between Slovakia and Poland. Dashed line represents border of the Tatra National Park. Area with left-hatching represents windstorm calamity in 2004. Black point in the index figure indicates location of the study area in European context.

assessment is based on results of Holko et al. [29], who found that one year of precipitation deficits leads to depletion of water basins in the Tatra Mountains, which had significant impact on ecosystems of the National Park.

\section{Materials and Methods}

2.1. The Area Specification. Tatra National Park is located in the Tatra Mountains (north Slovakia), the highest range in the Carpathian Mountains (the highest peak is Gerlachovský štít Mt., $2655 \mathrm{~m}$ a.s.l.). Two-thirds of the range belongs to Slovakia and one-third to Poland. Surrounding areas of mountains consist of the Oravské Beskydy Mts. (northwest) with highest peak Babia Hora, $1725 \mathrm{~m}$ a.s.l., Oravská Magura Mts. (west) reaching the height of $1394 \mathrm{~m}$ a.s.l. at Minčol peak, Nízke Tatry Mts. (south) with the maximum altitude at Dumbier Peak (2043 m a.s.1.), and Spiššská Magura Mts. with Levočské Vrchy Mts. (east) reaching up to $1289 \mathrm{~m}$ a.s.l. at the Čierna Hora Peak. The massive of the Tatra Mts. is open only from north to northnorthwest, where a depression area is locatedSubcarpathia (Poland). South of the Tatra Mts., the Liptovská Kotlina valley is located, which forms the southern border of the Tatra National Park and foothills of the Tatra Mts. (Figure 1).

The relief of the Tatra Mts. was created by glacial activity in the last ice age [35]. Subspecies endemic to the Tatra Mts. (e.g., Alpine marmot [Marmota marmota latirostris] and Tatra chamois [Rupicapra rupicapra tatrica], Carabids [Deltomerus tatricus, Nebria tatrica]) also date back to this era. Area of this unique species is located mostly over $1500 \mathrm{~m}$ a.s.l.

Geomorphologically, the mountains are divided into the West (Západné Tatry) and East Tatra Mts. (Východné Tatry). West Tatra Mountains are lower (highest peak is Bystrá, 
TABLE 1: Meteorological stations used in this study with their selected parameters.

\begin{tabular}{|c|c|c|c|c|c|c|c|}
\hline Station & ID number & North $\varphi$ & East $\lambda$ & $\begin{array}{c}\text { Altitude } \\
(.)\end{array}$ & $\begin{array}{l}\text { Precipitation } \\
(\mathrm{mm} / \text { year })^{* *}\end{array}$ & $\begin{array}{l}\text { Potential ET } \\
(\mathrm{mm} / \text { year })^{* * *}\end{array}$ & Time period \\
\hline Červený Kláštor & 1 & $49^{\circ} 23^{\prime}$ & $20^{\circ} 25^{\prime}$ & 463 & 792 & 500 & 1961-2010 \\
\hline Lipt. Mikuláš ${ }^{*}$ & 2 & $49^{\circ} 05^{\prime}$ & $19^{\circ} 36^{\prime}$ & 569 & 657 & 550 & 1961-2007 \\
\hline Podolínec & 3 & $49^{\circ} 15^{\prime}$ & $20^{\circ} 32^{\prime}$ & 573 & 720 & 525 & $1961-2010$ \\
\hline Liptovský Hrádok & 4 & $49^{\circ} 2^{\prime}$ & $19^{\circ} 43^{\prime}$ & 640 & 696 & 525 & $1961-2010$ \\
\hline Liesek $^{*}$ & 5 & $49^{\circ} 21^{\prime}$ & $19^{\circ} 40^{\prime}$ & 692 & 811 & 425 & 1961-2007 \\
\hline Poprad & 6 & $49^{\circ} 4^{\prime}$ & $20^{\circ} 14^{\prime}$ & 694 & 599 & 575 & 1961-2010 \\
\hline Habovka* $^{*}$ & 7 & $49^{\circ} 16^{\prime}$ & $19^{\circ} 36^{\prime}$ & 745 & 936 & 425 & 1980-2002 \\
\hline Huty & 8 & $49^{\circ} 8^{\prime}$ & $19^{\circ} 33^{\prime}$ & 808 & 918 & 375 & $1961-2010$ \\
\hline Tatranská Lomnica & 9 & $49^{\circ} 9^{\prime}$ & $20^{\circ} 17^{\prime}$ & 827 & 797 & 475 & $1961-2010$ \\
\hline Podspády & 10 & $49^{\circ} 16^{\prime}$ & $20^{\circ} 10^{\prime}$ & 913 & 1166 & 375 & 1961-2010 \\
\hline Podbanské & 11 & $49^{\circ} 8^{\prime}$ & $19^{\circ} 54^{\prime}$ & 972 & 959 & 475 & $1961-2010$ \\
\hline Tatranská Javorina & 12 & $49^{\circ} 15^{\prime}$ & $20^{\circ} 8^{\prime}$ & 1007 & 1305 & 375 & $1961-2010$ \\
\hline Starý Smokovec ${ }^{*}$ & 13 & $49^{\circ} 8^{\prime}$ & $20^{\circ} 13^{\prime}$ & 1010 & 857 & 475 & $1961-1990$ \\
\hline Hrebienok ${ }^{*}$ & 14 & $49^{\circ} 9^{\prime}$ & $20^{\circ} 13^{\prime}$ & 1270 & 1024 & 425 & 1961-1990 \\
\hline Štrbské Pleso & 15 & $49^{\circ} 7^{\prime}$ & $20^{\circ} 4^{\prime}$ & 1354 & 1026 & 425 & 1961-2010 \\
\hline Skalnaté Pleso & 16 & $49^{\circ} 11^{\prime}$ & $20^{\circ} 14^{\prime}$ & 1778 & 1351 & 375 & 1961-2010 \\
\hline Lomnický Štít & 17 & $49^{\circ} 11^{\prime}$ & $20^{\circ} 12^{\prime}$ & 2635 & 1498 & 325 & $1961-2010$ \\
\hline
\end{tabular}

${ }^{*}$ Station without calculated trend analysis. ${ }^{* *}$ Average precipitation amount calculated within the time period. ${ }^{* * *}$ Potential evapotranspiration totals calculated by Tomlain (2002) [34].

$2248 \mathrm{~m}$ a.s.1.) than East Tatra Mts. with the highest peak Gerlachovský štít (2655 m a.s.l.). The East Tatra Mts. consist of the Vysoké Tatry Mts. and Belianske Tatry Mts. The southeast region of the study area was impacted by windstorms, especially in 2004 (Figure 1).

2.1.1. Climate of the Tatra Mountains. Geomorphology of the Mountains and surrounding areas influences the prevailing winds in the area [36]. Prevailing winds on the peak station (Lomnický Štít Peak 2655 m a.s.l., the second highest peak in the Tatra Mountains) blow from the north and northwest sector as well as on the lowland station Červený Kláštor ( $463 \mathrm{~m}$ a.s.l.) located northeast of the mountains beyond the lee effect of the Tatra Mountains massive (Figure 2). In contrast, a predominantly west wind direction is measured at stations located south of the mountains (Poprad, $694 \mathrm{~m}$ a.s.l., or Liptovský Hrádok, 640 m a.s.l.).

Precipitation amounts in the area vary from the $599 \mathrm{~mm} /$ year at the station Poprad in the Popradská kotlina valley to the maximum at the Lomnický štít peak $(2635 \mathrm{~m}$ a.s.l.) with $1498 \mathrm{~mm} /$ year (Table 1). However, the effect of the mountain lee is visible in the precipitation amounts. While the precipitation amount at the lowest station Červený Kláštor (463 m a.s.l.) situated northeasterly of the mountain ridge is $792 \mathrm{~mm}$ /year, the stations Liptovský Mikuláš (569 m a.s.l.) and Liptovský Hrádok (640 m a.s.l.) situated in the Liptovská kotlina valley southerly of the mountain ridge vary from 657 to $696 \mathrm{~mm} /$ year. Localization of the mentioned stations is depicted in the Figure 2. The same effect is visible also at the station Poprad (694 $\mathrm{m}$ a.s.1.) located in the Popradská kotlina valley southeast of the mountain ridge.

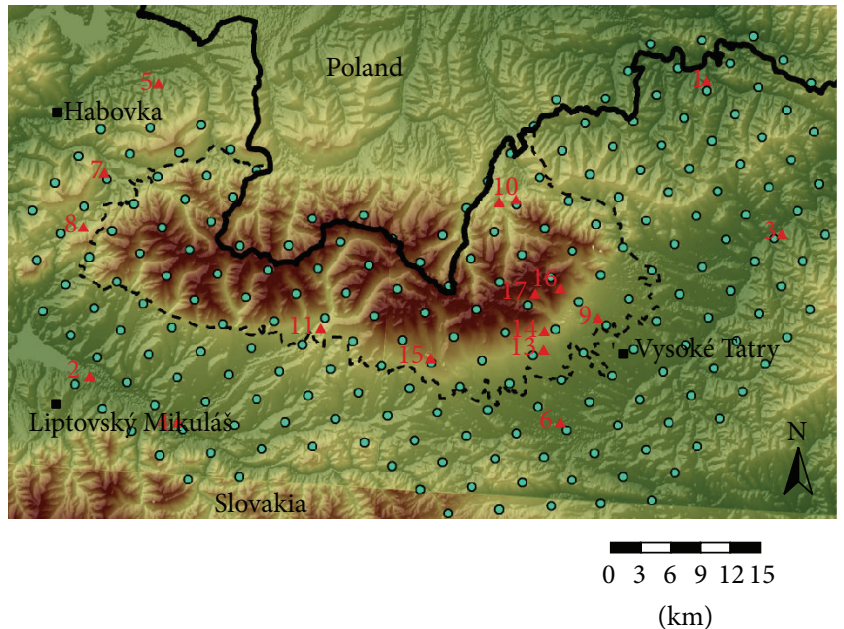

FIGURE 2: Localization of the used meteorological stations is depicted by triangles with number. Number near triangle corresponds to ID number of the station from Table 1. Circles represent grid points used in the GIS spatial analyses. Dashed line represents border of the Tatra National Park. Solid line depicts national boundary.

Potential evapotranspiration at all the stations around the Tatra Mountains ranges from $325 \mathrm{~mm}$ at the Lomnický štít peak (2635 m a.s.l.) to $550 \mathrm{~mm}$ per year at the Poprad station in the Popradská kotlina valley (694 m a.s.l.) [34]. As shown in the Table 1 at all the stations, the potential evapotranspiration is lower than precipitation totals. However, we see that at the stations situated southerly of the mountain ridge 
(leeward) in the Popradská kotlina and Liptovská kotlina valleys (e.g., Liptovský Mikuláš and Poprad) the precipitation surplus is relatively low (e.g., at the station Poprad $24 \mathrm{~mm}$ and at the station Liptovský Mikuláš 107 mm).

\subsection{Methods of Drought Analyses}

2.2.1. The Standardized Precipitation Index (SPI). The Standardized Precipitation Index [31] is drought index calculated on the basis of the probability of the occurrence of certain amount of precipitation in given time period. The calculation requires a long-term monthly precipitation database with 30 years or more of data. The probability distribution function is derived from the long-term record by fitting a gamma function to the data. The cumulative distribution is then transformed using equal probability to a normal distribution with a mean of zero and standard deviation of one, so the values of the SPI are really in standard deviations [37]. Entire mathematical descriptions of the principles and calculation of the SPI are given in [37]. Positive SPI values indicate greater than median precipitation, while negative SPI values indicate less than median precipitation. The magnitude of departure from zero represents probability of occurrence, so decisions can be made based on this SPI value. Thus SPI values of less than -1.0 occur 16 times in 100 years, an SPI of less than -2.0 occurs two to three times in 100 years, and an SPI of less than -3.0 occurs once in approximately 200 years. The SPI can be calculated for a variety of timescales. This allows the SPI to monitor short-term water supplies (such as soil moisture) and longer-term water resources such as groundwater supplies or lake levels [38].

2.2.2. Data. Inputs for indices are monthly precipitation totals from 17 meteorological stations (Table 1) of the Slovak Hydrometeorological Institute (SHMI) in the period 19612010 situated in the area of the Tatra National Park. Precipitation data for stations with the shorter period (i.e., Habovka 1980-2002, Starý Smokovec, Hrebienok 1961-1990, Liesek 1961-2007, and Liptovský Mikuláš 1961-2007) were used as supplementary stations for spatial model improvement. For these stations long-term trend analyses were not prepared because of a shorter time period, which could have an impact on the SPI parameters.

2.2.3. Data Processing in SPI Analyses. Since all the data sets of the calculated SPI were normally distributed (normality was tested using Kolmogorov-Smirnov test) linear function and Student's $t$-test for trend analyses have been applied according to Yue and Pilon [39]. Trend analyses using linear trend were made for each station separately, except those stations with shorter observation periods as mentioned in Table 1. Trends were tested on significance by Student's $t$ test on the significance level $\alpha=0.05$. This process has been carried out in order to get information of altitudinal variability of drought trends in the period 1961-2010.

To characterize the general overview of drought occurrence over the study region, an average SPI based on the stations SPI values (from Table 1) was constructed. In all the analyses in this paper, the 12-month SPI was used to evaluate a severe drought episodes in the area. The reason to use 12-month SPI for long-term drought assessment (as mentioned in introduction) is based on results of Holko et al. [29], who found that one year of precipitation deficits leads to depletion of water basins in the Tatra Mountains, which had significant impact on ecosystems of the National Park. In order to obtain information about alternation between wet and dry long-term episodes, curvilinear regression (fourthorder polynomial) has been constructed. The reason is that the curvilinear regression depicts periods or specific cycles (alternation between dry and wet episodes) more illustratively compared to another regression function (e.g., linear, moving average) as mentioned by Gulrado and Bermúdez [40].

2.2.4. Data Processing in Spatial Evaluations. To identify the geospatial pattern and distribution of drought within the seasons, 12-month SPI values were used and interpolated using the following GIS techniques based on the spatial average of two (modeled and observed) layers.

The first layer contains the spatial information of drought conditions provided by nodes (grid points) with appropriate SPI values. Here the SPI was calculated with precipitation data obtained by approximation between precipitation and altitude. The challenge was to find the best fit function able to identify the trend and effectively approximate the relationship between precipitation and altitude. However, we used the simple linear function to estimate the precipitation values. The results showed a strong correlation (i.e., $R^{2}=0.6977$ with $\alpha=0.01)$. Finally, the estimated values were plotted and interpolated using SPLINE function in GIS. Figure 2 shows the net of 220 nodes (grid points) used in GIS processing.

The second layer was obtained by spatial interpolation of the SPI station based data obtained by the meteorological stations around the Tatra Mountains (Figure 2 and Table 1). The spatial interpolation of the second layer was carried out using the SPLINE interpolation function.

Finally, the spatial average of the first and the second layer was processed (using raster calculator) and used as a drought spatial distribution model for the Tatra Mountains.

The spatial model was evaluated by comparing the observed and modeled precipitation totals for three different precipitation scenarios: above average, below average, and average precipitation. To represent these three scenarios, 2010, 2003, and 1997 were selected. Correlation of precipitation totals obtained using selected modeled grid points with the nearest totalizer rain gauge showed statistical significance evaluated by Pearson correlation ranging from 0.9583 to 0.9859. The spatial model and all trend analysis have been tested and approved using $t$-test at the significance level $\alpha=$ 0.05 .

\section{Results and Discussion}

3.1. General Overview of a Drought Occurrence in the Tatra Mountains Region. Niedźwiedź et al. [41], Labudová et al. [42], Büntgen et al. [4], and Konček et al. [25] indicated that the long-term variations in precipitation regime around the Tatra Mountains mostly depends on the atmospheric 


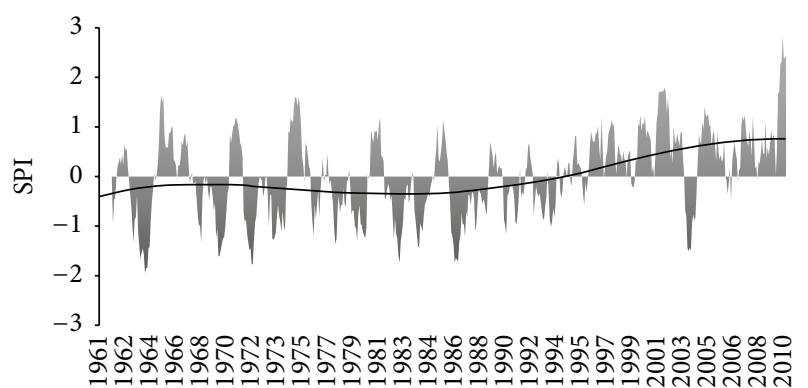

FIgURE 3: Average 12-month SPI for the Tatra Mountains region. The trend line is constructed by the curvilinear regression (fourth-order polynomial).

circulation, especially by westerly zonal circulation because of the mountains' orientation along a zonal air flow. Therefore, to understand the general conditions and occurrence of severe droughts over the region, we have used the average precipitation time-series pattern based on all station data (Table 1) except stations with shorter observations (i.e., Habovka, Starý Smokovec, Hrebienok, Liesek, and Liptovský Mikuláš). Figure 3 shows this temporal distribution of precipitation variations from 1961 to 2010 using the SPI for 12 months. The figure shows the occurrences of all drought episodes (negative values) during the 1961-2010 period. Thus, six severe drought episodes $(\mathrm{SPI} \leq-1.5)$ using the 12 -month SPI are identified. The 12-month SPI values indicated that an extreme drought episode was observed in the period from 1963 to 1965, which was the most intense drought during the record. Exceptional dry periods with frequent occurrences of drought situations persisted in 1962-1964, 1967-1969, 1971-1974, 1977-1980, 1982-1985, 1986-1989, and 2003 over the Tatra Mountains. A particularly long-lasting dry period also occurred from 1990 to 1995. These detected episodes correlate with results of Demeterová and Škoda [8]. The authors describe that hydrological drought over the study area persisted in 1963, 1972-1974, 1976, 1978, 19821985, 1987-1994, and 2003. An increase in wet episodes after 1995 (except pan-European drought of 2003) corresponds to results explained by Büntgen et al. [4] and Lapin and Faško [43] that the precipitation totals in the study area are mostly driven by western/northwestern zonal air flow. Niedźwiedź et al. [19] and Lapin and Tomlain [44] imply that the significant increase of the west cyclonal situation was recorded in this area after the first half of the 1990s. This correlates with an increase in wet situations shown by the SPI after 1993. However Niedźwiedź et al. [19] and Lapin and Faško [43] indicated that these changes in circulation patterns are cyclic, with an approximately 30-year period.

Our findings (based on approximate estimation of inflection points in the polynomial trend of the SPI) also showed that periodicity. Actually inflection points of the polynomial trend were detected in 1968 and 1998 (i.e., 29-year period). This result corresponds also with Pekárová et al. [20], which imply the same frequency based on analyzed long-term water levels of the central European rivers. Based on this we argue that the current "wet period" started from early nineties could
TABLE 2: Correlation coefficients of the SPI trends at the stations around the Tatra Mountains in context of altitude in the period 19612010.

\begin{tabular}{lcc}
\hline Station & $\begin{array}{c}\text { Altitude } \\
(\mathrm{m} \text { a.s.l. })\end{array}$ & $\begin{array}{c}\text { Coefficient of correlation } \\
R^{2}\end{array}$ \\
\hline Červený Kláštor & 463 & $\mathbf{0 . 2 0 9 9}$ \\
Podolínec & 573 & 0.0136 \\
Liptovský Hrádok & 640 & 0.0319 \\
Poprad & 694 & 0.0292 \\
Huty & 808 & 0.0314 \\
Tatranská Lomnica & 827 & 0.0108 \\
Podspády & 913 & $\mathbf{0 . 1 7 4 4}$ \\
Podbanské & 972 & $\mathbf{0 . 0 6 0 4}$ \\
Tatranská Javorina & 1007 & $\mathbf{0 . 1 9 9 1}$ \\
Štrbské pleso & 1354 & $\mathbf{0 . 1 3 5 6}$ \\
Skalnaté pleso & 1778 & $\mathbf{0 . 1 2 3 4}$ \\
Lomnický štít & 2635 & $\mathbf{0 . 4 7 2 0}$ \\
\hline
\end{tabular}

Marked in bold indicates a statistically significant trend at the level of significance $\alpha=0.05$.

be interrupted by a dry period in the future decade. This argument should be taken in the account in the National Park management plan for future decades. In addition, with the observed and anticipated regional temperature increase $[15,21]$, the drought severity could be worse in the future.

3.2. Time Series Trend Analysis of SPI for 12 Months at the Stations in the Area of the Tatra Mountains. Analysis of the time series showed an increase in the number of wet episodes of SPI at all stations analyzed after 1995. However, this increasing trend is not significant (at the significance level $\alpha=0.05$ ) for the stations located at lower altitudes, that is, Podolínec, Liptovský Hrádok, Poprad, Huty, and Tatranská Lomnica, except for one station Červený Kláštor (Table 2). This station is situated over the northeastern Tatra Mountains, where it is beyond the influence of rain shadow. Statistically, trends toward wet conditions over the higher altitudes over $900 \mathrm{~m}$ a.s.l. (i.e., Podspády, Podbanské, Tatranská Javorina, Štrbské Pleso, Skalnaté Pleso, and Lomnický štít) were found significant at the significance level $\alpha=0.05$ (Table 2). Thus it seems that the habitats of the Tatra National Park including habitats of periglacial relict species are in "relatively drought-safer altitudinal zone," because the core area of the biosphere reserve, where habitats of this unique species are located, starts at $1500 \mathrm{~m}$ a.s.1. [22-24]. However, due to a relatively low precipitation surplus on stations in lower altitudes, what was shown in Table 1, and due to suggested cyclicity of the "wet" and "dry" periods in combination with observed temperature increase in Tatra Mountains [21], drought risk could increase in the future, especially during the prolonged drought episodes. This potential risk (based on ecological analyses) was outlined in results of Bitušík and Koppová [30], Konôpka and Konôpka [12], and Hlásny and Turćáni [28]. We have to consider that this could cause a potential ecological pressure, for example, by spreading of 


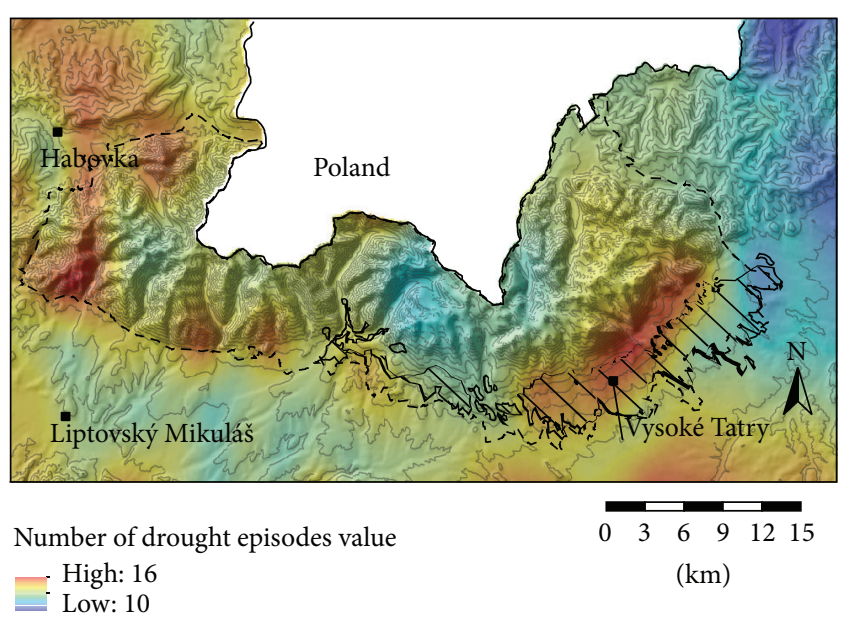

FIgURE 4: Number of all drought situations according to the 12month SPI. Red color represents higher frequency of drought situations. Dashed line represents border of the National Park. Square represents city or settlement. Area with left-hatching represents calamity in 2004.

lowland xerophilous species to habitats of middle altitudes (buffer zones and transition areas of the park) because of their better adaptation to dry climatic conditions in contrast to mountain or even alpine stenobionts as shown in Šustek and Vido [45].

3.3. Spatial Patterns of Drought Episode Occurrences across the Tatra National Park. In general, precipitation totals relate proportionally to altitude [46]. However Konček et al. [25] argued that the orographic diversity of the Tatra Mountains modifies this dependence by local precipitation shadows. This fact could have a significant impact on precipitation totals and therefore number of drought situations in the lee ward areas. Spatial projection of areas with similar number of drought episodes (using the 12-month SPI) identifies a potential drought prone areas. These locations could be affected more often in contrast to other areas especially during the prolonged episodes with precipitation deficit. Spatial projection of the 12-month SPI depicts the prevalence of potentially severe drought episodes because of the previously mentioned impact of long-lasting precipitation deficits on water depletion in this area [29].

Figure 4 illustrates that the area with higher frequency of drought episodes can be divided into three main droughtprone subareas. The first is situated in west and northwest of the Tatra National Park. This area is influenced by precipitation shadow of the Oravská Magura and Oravské Beskydy Mountains located northwest of the Tatra National Park.

The second main drought-prone area is located on the lee side of the main mountain ridge of High Tatra, east of the Tatranská Kotlina village to Vyšné Hágy settlement. Secondary maximums of drought episode prevalence are recorded in the area of the valleys Jamnická dolina, Bystrá dolina, and Račková dolina in the West Tatra Mountains around the mouth of the valleys Tichá dolina and Kôprová dolina near the Podbanské village and in the valleys Zadné
Med’odoly, Predné Med'odoly, Čierna javorová dolina, and Kolová dolina in the High Tatra. In contrast, locations with the lowest number of drought episodes are located outside of the influence of the rain shadow of the Tatra Mountains complex around the northeast headland of the mountains near meteorological station Červený Kláštor.

Finally the third area is the Popradska kotlina valley, southeast of the Tatra National Park. This area corresponds with the rain shadow in the Popradská kotlina and Spišská kotlina valleys, which is also noted by Konček et al. [25].

The most endangered (drought-prone) areas defined by number of drought episodes correspond in particular with the area of the massive windstorm of 2004 (spatial overlap reached $46 \%$ ). This huge wind damage caused devastation of the spruce forests in the area [47]. Thus the ecosystems are in the process of secondary succession. Ecosystems in early succession stages in the area could be therefore more affected by drought because of their lower resistance level to natural disturbances [48].

These facts imply a potential of drought risk for the forest ecosystem during its succession process. Moreover, in synergy with the predicted temperature (evapotranspiration) increase at the middle altitudes $[15,21]$ and possible decline of "wet situations" in the following decades (because of the mentioned multidecadal cycle) $[19,20,39]$ could be drought impact on this ecosystem worse in the future. So the restoration of the forests could be unpredictable and incalculable. Signals of such an ecological behavior were indicated by Šustek and Vido [45] (2013) in the structure of the sensitive ground beetle communities after the relatively hot and dry summer 2007 in the Tatra National Park.

\section{Conclusions}

This study showed that occurrence of drought has cyclic pattern with approximately 30 -year period. Almost all years in the last two decades were relatively "wet" except the 2003, which was short but severe drought. Because of this cyclic pattern of precipitation regime over the Tatra Mountains, we expect "dry" period with numerous drought episodes in subsequent decades. However, in this study, it was found that core areas of the biosphere reserve of the Tatra National Park inhabited by the unique species (altitudes over $1500 \mathrm{~m}$ a.s.l.) are in relatively "drought-safer altitudinal zone" based on SPI station based trend analyses. Unfortunately, ecosystems of lower altitudes (up to $900 \mathrm{~m}$ a.s.l.) could be impacted by drought in anticipated dry period, due to presented low precipitation surplus and low significance of the SPI trend, respectively.

The SPI spatial analyses result in the fact that the occurrence of drought episodes is influenced by the precipitation shadow of the Tatra Mts. range and surrounding mountains situated north and to northwest of the Tatra Mts. Thus the occurrence of drought is more likely at the south and southeast regions of the mountains than at the north/northeast windward part of the Tatra Mountains. In addition, another drought prone area was also indicated in the West Tatra Mts. This area is influenced by the Oravské Beskydy and Oravská Magura Mts. located to the northwest. 
On the other hand, the south and southeast part of the National Park was influenced by a severe windstorm in 2004. From the ecological point of view it is interesting that the area of the windstorm spatially correlates with identified droughtprone areas (spatial overlap is $46 \%$ ). Therefore ecosystem restoration in this area could be affected by potential drought episodes in the future. We recommend that above presented information should be taken into account by decision makers responsible for forest restoration management within that affected area.

\section{Conflict of Interests}

The authors declare that there is no conflict of interests regarding the publication of this paper.

\section{Acknowledgments}

This contribution was supported by research grants of The Ministry of Education, Science, Research and Sport of the Slovak Republic: VEGA nos. 2/0101/14, 1/0463/14, 1/0589/15, and by grant of the Slovak Research and Development Agency no. APVV-0480-12 and no. APVV-0303-11.

\section{References}

[1] S. M. Vicente-Serrano, C. Gouveia, J. J. Camarero et al., "Response of vegetation to drought time-scales across global land biomes," Proceedings of the National Academy of Sciences of the United States of America, vol. 110, no. 1, pp. 52-57, 2013.

[2] C. D. Allen, A. K. Macalady, H. Chenchouni et al., "A global overview of drought and heat-induced tree mortality reveals emerging climate change risks for forests," Forest Ecology and Management, vol. 259, no. 4, pp. 660-684, 2010.

[3] M. Trnka, R. P. Rötter, M. Ruiz-Ramos et al., "Adverse weather conditions for European wheat production will become more frequent with climate change," Nature Climate Change, vol. 4, no. 7, pp. 637-643, 2014.

[4] U. Büntgen, R. Brázdil, D. Frank, and J. Esper, “Three centuries of Slovakian drought dynamics," Climate Dynamics, vol. 35, no. 2, pp. 315-329, 2010.

[5] P. Ciais, M. Reichstein, N. Viovy et al., "Europe-wide reduction in primary productivity caused by the heat and drought in 2003," Nature, vol. 437, no. 7058, pp. 529-533, 2005.

[6] P. Hlavinka, M. Trnka, D. Semerádová, M. Dubrovský, Z. Žalud, and M. Možný, "Effect of drought on yield variability of key crops in Czech Republic," Agricultural and Forest Meteorology, vol. 149, no. 3-4, pp. 431-442, 2009.

[7] J. Poórová, L. Blaškovičová, P. Škoda, and V. Šimor, “Trends of minimum annual and monthly flows in Slovakia," in Zborník Abstraktov, Odborný Seminár Sucho a Jak mu Čelit, pp. 20-23, Praha, Slovakia, 2013.

[8] B. Demeterová and P. Škoda, "Low flow in selected streams of Slovakia," Journal of Hydrology and Hydromechanics, vol. 57, no. 1, pp. 55-69, 2009.

[9] A. H. Fink, T. Brücher, A. Krüger, G. C. Leckebusch, J. G. Pinto, and U. Ulbrich, "The 2003 European summer heatwaves and drought-synoptic diagnosis and impacts," Weather, vol. 59, no. 8, pp. 209-216, 2003.
[10] J. Škvarenina, J. Miňd'áš, J. Holécy, and J. Tuček, "Analysis of the natural and meteorological conditions during two largest forest fire events in the Slovak Paradise National Park," in Proceedings of the International Bioclimatological Workshop, p. 11, Bratislava, Slovakia, September 2003.

[11] M. J. Klapwijk, M. P. Ayres, A. Battisti, and S. Larsson, "Assessing the impact of climate change on outbreak potential," in Insect Outbreaks Revisited, pp. 429-450, Blackwell Publishing, Oxford, UK, 2012.

[12] J. Konôpka and B. Konôpka, "Influence of main kinds of abiotic harmful agents on forest ecosystems, research and practice," Reports of Forestry Research, vol. 47, no. 1, p. 40, 2002.

[13] M. Trnka, J. Kylselý, M. Možný, and M. Dubrovský, “Changes in Central European soil moisture availability and circulation patterns in 1881-2005," International Journal of Climatology, vol. 29, no. 5, pp. 655-672, 2009.

[14] B. Lloyd-Hughes and M. A. Saunders, "A drought climatology for Europe," International Journal of Climatology, vol. 22, no. 13, pp. 1571-1592, 2002.

[15] M. Lapin, M. Gera, J. HrvoL', M. Melo, and J. Tomlain, "Possible impacts of climate change on hydrologic cycle in Slovakia and results of observations in 1951-2007," Biologia, vol. 64, no. 3, pp. 454-459, 2009.

[16] M. Lapin and M. Melo, "Methods of climate change scenarios projection in Slovakia and selected results," Journal of Hydrology and Hydromechanics, vol. 52, no. 4, pp. 224-238, 2004.

[17] J. Škvarenina, J. Tomlain, J. Hrvol, J. Škvareninová, and P. Nejedlík, "Progress in dryness and wetness parameters in altitudinal vegetation stages of West Carpathians: time-series analysis 1951-2007," Időjárás, vol. 113, no. 1-2, pp. 47-54, 2009.

[18] P. Faško, M. Lapin, and J. Pecho, "20-Year extraordinary climatic period in Slovakia,” Meteorologický Časopis, vol. 11, pp. 99-105, 2008.

[19] T. Niedźwiedź, R. Twardosz, and A. Walanus, "Long-term variability of precipitation series in east central Europe in relation to circulation patterns," Theoretical and Applied Climatology, vol. 98, no. 3-4, pp. 337-350, 2009.

[20] P. Pekárová, P. Miklanek, and J. Pekar, "Long-term trends and runoff fluctuations of European rivers," in Climate Variability and Change: Hydrological Impacts, Proceedings of the Fifth FRIEND World Conference held at Havana, Cuba, vol. 308, pp. 520-525, IAHS Publication, 2006.

[21] A. Pribullová, M. Chmelík, and J. Pecho, "Air temperature variability in the high tatra mountains," in The Carpathians: Integrating Nature and Society Towards Sustainability, Environmental Science and Engineering, pp. 111-130, Springer, Berlin, Germany, 2013.

[22] L. Vlček, "Geographical distribution of chamois (Rupicapra rupicapra L.) in the Western Carpathians territory during the last Glacial and the Holocene," Acta Carsologica Slovaca, vol. 48, no. 1, pp. 83-98, 2010.

[23] P. Bačkor, "Current distribution of the Alpine Marmot (Marmota marmota) in the Nízke Tatry Mts., Slovakia (Rodentia: Sciuridae)," Lynx, Series Nova, vol. 40, no. 1, pp. 5-13, 2009.

[24] J. Kliment, "Thoughts on recent phytogeographical regionalisation of Slovakia (notes to selected phytochorions)," Bulletin Slovenskej Botanickej Spoločnosti, vol. 25, pp. 199-224, 2003.

[25] M. Konček, I. Bohuš, V. Briedoň et al., Climate of the Tatra Mountains, Veda, Bratislava, Veda, Bratislava, Slovakia, 1974.

[26] M. Dubrovsky, M. D. Svoboda, M. Trnka et al., "Application of relative drought indices in assessing climate-change impacts 
on drought conditions in Czechia," Theoretical and Applied Climatology, vol. 96, no. 1-2, pp. 155-171, 2009.

[27] SLS, Climate of the High Tatra Mountains, Scientia, Tatranská Lomnica, Slovakia, 2009.

[28] T. Hlásny and M. Turcáni, "Insect pests as climate change driven disturbances in forest ecosystems," in Bioclimatology and Natural Hazards, pp. 165-177, Springer, Dordrecht, The Netherlands, 2009.

[29] L. Holko, M. Dóša, and P. Škoda, "Depletion curves and hydrological reaction of mountain river basins," in Hydrologie Malého Povodí, K. Brych and M. Tesař, Eds., pp. 125-131, Ústav pro Hydrodynamiku AVČR \& CHMI, Praha, Slovakia, 2014.

[30] P. Bitušík and K. Koppová, "Macrozoobenthos of the glacial lakes in the Low Tatras (West Carpathians)," Biologia, vol. 52, no. 2, pp. 227-232, 1997.

[31] T. B. McKee, J. N. Doeksen, and J. Kleist, "The relationship of drought frequency and duration to time scales," in Proceedings of the 8th Conference on Applied Climatology, pp. 179-184, American Meteorological Society, Anaheim, Calif, USA, 1993.

[32] Y. He, J. Ye, and X. Yang, "Analysis of the spatio-temporal patterns of dry and wet conditions in the Huai River Basin using the standardized precipitation index," Atmospheric Research, vol. 166, pp. 120-128, 2015.

[33] J. Bazrafshan, S. Hejabi, and J. Rahimi, "Drought monitoring using the multivariate standardized precipitation index (MSPI)," Water Resources Management, vol. 28, no. 4, pp. 10451060, 2014.

[34] J. Tomlain, "Mean annual actual and potential evapotranspiration totals," in Landscape Atlas of the Slovak Republic, p. 96, Ministerstvo Životného Prostredia Slovenskej Republiky, Slovenská Agentúra Životného Prostredia, Bratislava, Slovakia, 2002.

[35] M. Mišík, Geological Excursions Around Slovakia, vol. 276, SPN, Bratislava, Slovakia, 1979.

[36] M. Lapin and M. Tekušová, "Wind speed and direction, exposure of territory to inversion," in Landscape Atlas of the Slovak Republic, p. 100, Ministerstvo Životného Prostredia Slovenskej Republiky, Slovenská Agentúra Životného Prostredia, Bratislava, Slovakia, 2002.

[37] D. C. Edwards and T. B. McKee, "Characteristics of 20th century drought in the United States at multiple time scales," in Climatology Report, vol. 97, Colorado State University, Fort Collins, Colo, USA, 1997.

[38] M. J. Hayes, M. D. Svoboda, D. A. Wilhite, and O. V. Vanyarkho, "Monitoring the 1996 drought using the standardized precipitation index," Bulletin of the American Meteorological Society, vol. 80, no. 3, pp. 429-438, 1999.

[39] S. Yue and P. Pilon, "A comparison of the power of the $t$ test, Mann-Kendall and bootstrap tests for trend detection," Hydrological Sciences Journal, vol. 49, no. 1, pp. 21-37, 2004.

[40] S. G. Gulrado and F. L. Bermúdez, "Trend of the rainfalls and temperatures in a small fluvial basin of peninsular semiarid south-east," Boletín de la Asociación de Geógrafos Españoles, vol. 56, pp. 473-478, 2011.

[41] T. Niedźwiedź, E. Łupikasza, I. Pińskwar, Z. W. Kundzewicz, M. Stoffel, and Ł. Małarzewski, "Variability of high rainfalls and related synoptic situations causing heavy floods at the northern foothills of the Tatra Mountains," Theoretical and Applied Climatology, vol. 119, pp. 273-284, 2014.

[42] L. Labudová, P. Št’astný, and M. Trizna, "The north atlantic oscillation and winter precipitation totals in Slovakia," Moravian Geographical Reports, vol. 21, no. 4, pp. 38-49, 2013.
[43] M. Lapin and P. Faško, "Precipitation and changes of the atmospheric circulation in the period 1874-1993 in Slovakia," Meteorologické Zprávy, vol. 49, pp. 1-11, 1996.

[44] M. Lapin and J. Tomlain, General and Regional Climatology, Vydavatel'stvo UK, Bratislava, Slovakia, 2001.

[45] Z. Šustek and J. Vido, "Vegetation state and extreme drought as factors determining differentiation and succession of Carabidae communities in forests damaged by a windstorm in the High Tatra Mts," Biologia, vol. 68, no. 6, pp. 1198-1210, 2013.

[46] M. D. Eyre, S. P. Rushton, M. L. Luff, and M. G. Telfer, "Investigating the relationships between the distribution of British ground beetle species (Coleoptera, Carabidae) and temperature, precipitation and altitude," Journal of Biogeography, vol. 32, no. 6, pp. 973-983, 2005.

[47] P. Fleischer, "Windfall research and monitoring in the High Tatra Mts., objectives, principles, methods, and current status," Contributions to Geophysics and Geodesy, vol. 38, no. 3, pp. 233248, 2008.

[48] R. Šoltés, J. Školek, Z. Homolová, and Z. Kyselová, "Early successional pathways in the Tatra Mountains (Slovakia) forest ecosystems following natural disturbances," Biologia, vol. 65, no. 6, pp. 958-964, 2010. 

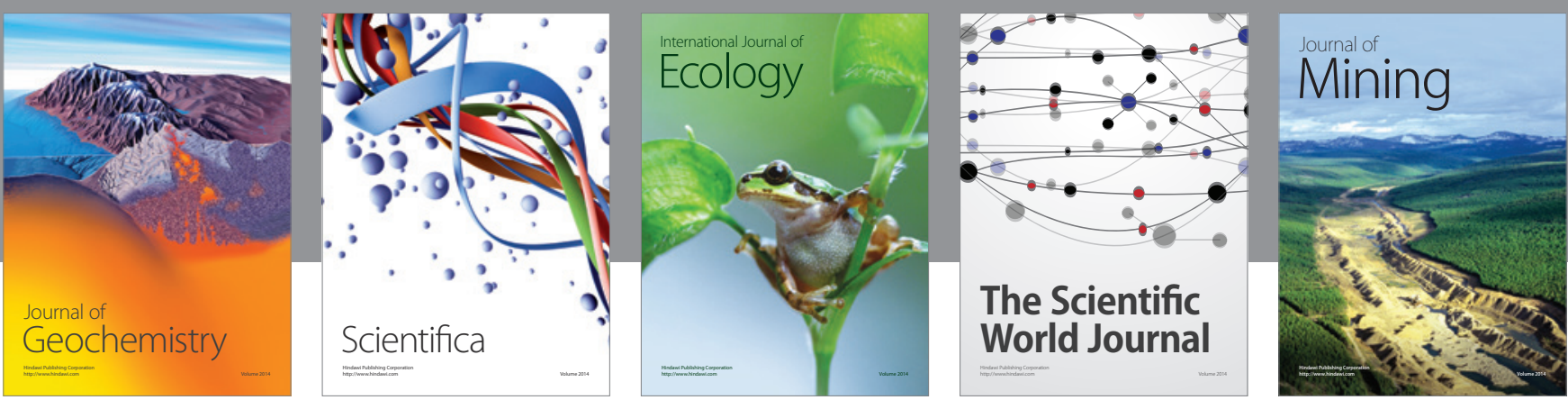

The Scientific World Journal
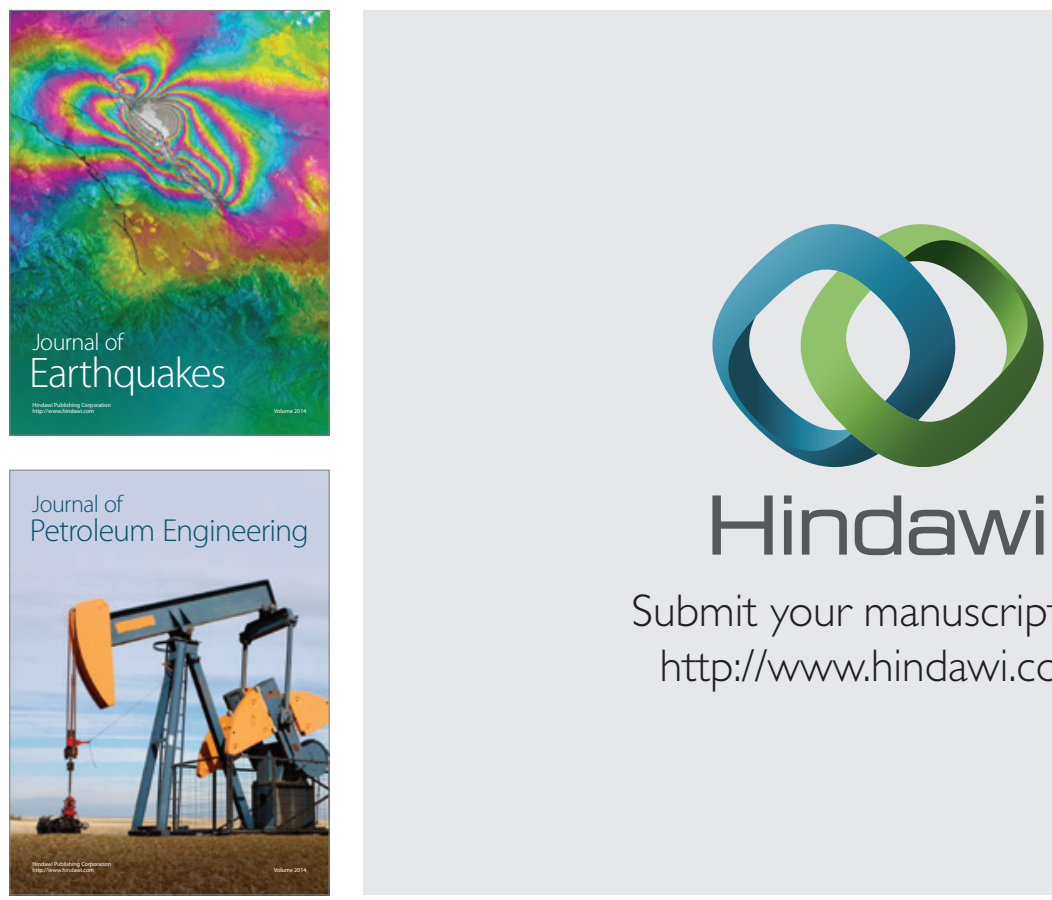

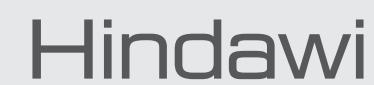

Submit your manuscripts at

http://www.hindawi.com
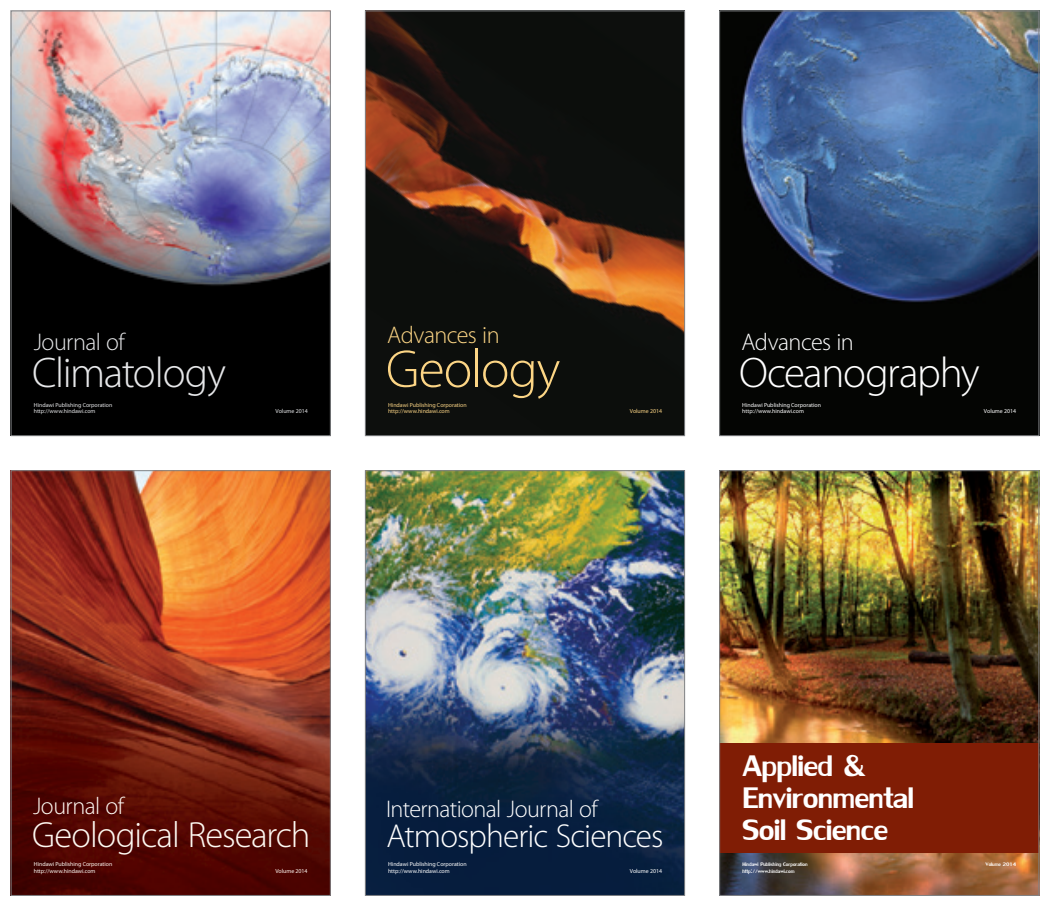
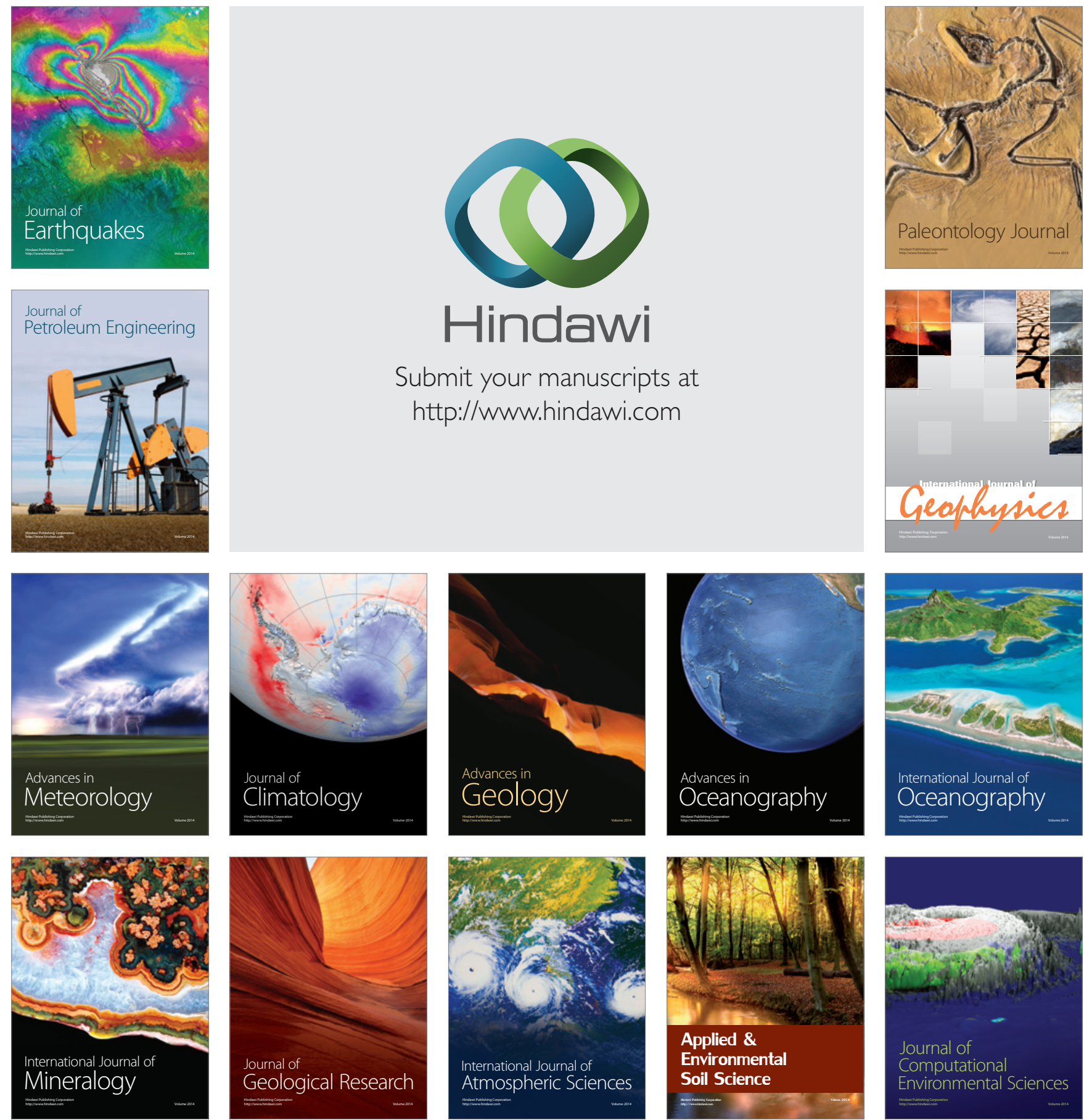